\title{
RESET
}

Recherches en sciences sociales sur Internet

\section{Rethinking heritagization through the digitization of familial archives}

The case of Léo Gravelle's website

Repenser la patrimonialisation à travers la numérisation d'archives familiales.

Le cas du site internet de Léo Gravelle

\section{Fannie Valois-Nadeau}

\section{OpenEdition}

\section{Journals}

Electronic version

URL: http://journals.openedition.org/reset/773

DOI: $10.4000 /$ reset.773

ISSN: 2264-6221

\section{Publisher}

Association Recherches en sciences sociales sur Internet

\section{Electronic reference}

Fannie Valois-Nadeau, « Rethinking heritagization through the digitization of familial archives », RESET [Online], 6 | 2017, Online since 30 October 2016, connection on 30 April 2019. URL : http:// journals.openedition.org/reset/773 ; DOI : 10.4000/reset.773

This text was automatically generated on 30 April 2019.

(c) Association Recherches en sciences sociales sur Internet 


\title{
Rethinking heritagization through the digitization of familial archives
}

\author{
The case of Léo Gravelle's website \\ Repenser la patrimonialisation à travers la numérisation d'archives familiales. \\ Le cas du site internet de Léo Gravelle
}

Fannie Valois-Nadeau

Acknowledgments: I want to thank Denys and Léo Gravelle, Alison Loader, Estée Fresco, Constance

Lafontaine, Kim Sawchuk and the Ageing Communication and Technologies (ACT) network for

their precious help.

\section{Introduction}

1 In 2008, Denys Gravelle created a French-language website in tribute to his father, Léo Gravelle (www.leogravelle.com), who passed away in October 2013 at the age of $88^{1}$. Over than sixty years earlier, Léo Gravelle had been a professional hockey player with the Montreal Canadiens, a popular sports team that celebrated its one-hundredth anniversary in 2009. With the recent interviews he gave on television and in local newspapers, Léo Gravelle has re-surfaced in the media landscape and, paradoxically, has become more publicly prominent in the years after his retirement. By featuring private photographs alongside newspaper clippings and memorabilia that the Gravelle family had previously kept in eight photo albums, the website became an alternate venue to circulate and render accessible Léo's history for the generations that didn't see him play hockey, while giving rise to a display of archival material previously restricted to a private family collection. By serving as the venue that keeps, protects and exposes this archival material, the website has rendered visible Léo's hockey career through the display of his personal souvenirs. Similar to a shoebox that has held souvenirs for years (van Dijck, 2007), the website preserves (in public) significant artefacts. But also, like museum exhibitions and explanatory plaques posted at heritage sites, the website teaches audiences about a specific past. 
2 This article interrogates the process of heritagization that occurs through the digitization of family archives and explores how the Léo Gravelle website shares similar patterns with sites and objects that are usually considered to be "official heritage" (Smith, 2006). However, the fact that the digital heritagization practices are initiated by individuals - in this case family members - opens up and challenges the way heritage is generally understood and established. Unlike practices associated with official heritage preservation, which are sustained by cultural policies and allocated funding or placed under the umbrella of established institutions whose mandate is cultural preservation, this case study allows for an interrogation of what makes heritage and, more specifically, how the process of heritagization occurs when its content is not officially designated as heritage and performed outside of traditional venues (such as museums or tourist sites). As a way to provide a wide exposure of Léo's hockey past, facilitate public access to his personal archives that had been accumulated over many years, and ensure their preservation in the future, the creation of this website sheds light on heritage practices realized on a small and familial scale. Placing these questions within the context of consumer culture and sport-spectacle also contributes to challenge and displace traditional understandings of heritage, as a process that frequently overlaps with projects led by political and historical institutions.

3 This analysis of the Léo Gravelle website also raises a set of questions about the "digitalization" of the heritagization processes. The emergence of digital technology has created new objects that could be considered to be new forms of heritage (for example, websites, Internet links and other digital archives), as well as new sites for ensuring the preservation of non-digital archival material. However, this change does not necessarily mean that the same practices of heritagization are being reproduced in digital spaces. Given that, how can one approach the heritagization of Léo's hockey past as being dependent on its archive's digitization without reducing this process to the "newness" of the means through which it was realized? Doing heritagization on the web and through digital devices must inform the ways that we designate and protect what is considered as heritage. To address the above question and thereby avoid the trap of presentism, there is a need to explore different and new forms of heritagization in order to understand how this practice has been affected and transformed by digitization. I propose that the passage to "new" formats consequently gives rise to new configurations of heritagization.

4 Informed by recent works on unofficial and critical heritage (Harrison, 2013; Roberts \& Cohen, 2013; Smith, 2006) and situated in the fields of memory studies (especially within the current media turn in this field) and cultural studies, this paper explores the process of heritagizing the archives of a father, specifically one who had been a local celebrity. Drawing on an analysis of the website and an interview I conducted with the Gravelles (both father and son) ${ }^{2}$ (Valois-Nadeau, 2014), I examine how this process of heritagization is framed - and transformed - by the possibilities provided by digital technologies, as well as by the cultural practices and familial ties that lie at the heart of the project. As we will see with the case of this website, the growth and commercialization of technological devices have multiplied and widened processes of heritagization. Existing at the intersection of unofficial heritage, digital heritage and familial heritage, this website is the ideal case study to examine in order to deepen conventional understandings of heritagization practices. By exploring the Léo Gravelle website, this article also offers an incursion into the world of aging sportsmen and the culture of professional hockey in the province of Québec (Canada). 


\section{Digital commodities and the popularization of heritage practices}

5 Shortly after Léo's son Denys Gravelle retired, Denys and his spouse Lise (with the help of the new scanner bought especially for the task) began digitizing the eight photo albums dedicated to the collection of Léo's hockey memories. The couple patiently scanned newspaper clippings, official team photographs, documents of special events Léo had attended, original hockey cards, etc. to ensure that these documents would be conserved for the future. In being saved in digital format, these archives were henceforth protected from the wear of paper and any potential incidents that could alter these precious memories. As Denys explained during the interview, "we still have the original information stowed somewhere, but digitalized and printed. We put all the information in the website, for the family" (2012, my translation). Although digital devices can be criticized for frequently changing, and for tending to fall rapidly into disuse, it remains that, in the face of a heightened reliance on them, these devices can help create an alternate place dedicated for preservation that contributes to countering the alteration, or worse yet, the disappearance of photographs.

6 If Léo Gravelle's website appears at first sight to be a melting pot of different artefacts or a pell-mell shoebox recollecting memories of all sorts (Valois-Nadeau, 2014; van Dijck, 2007) ${ }^{3}$ that extend beyond the memories from his hockey career, I would instead suggest that this digital platform also acts as the trigger for new forms of family-based heritage. According to José van Dijck $(2005,2007)$, the recent commercialization and popularity of technological devices (such as scanners) have reconfigured the relation to family archives and created a new way for families to retrieve and conserve their own past. As she argues,

Commercial companies are quick to provide digital alternatives to familiar analogue forms, such as digital family albums, formatted weblogs or scrapbooks, to facilitate the storage and retrieval of recorded pieces. Not surprisingly, they tend to focus on the products of memory, turning mediated expression into prefabricated exercises based on conventional analogue genres [...] Some projects simply promise to solve the urgent shoebox problem, others intend to design completely new systems of memory storage and retrieval; yet further, others boast that their new software and hardware will revolutionize our very ability to remember. (van Dijck, 2005: 313)

7 Existing at the intersection of the construction of familial heritage and new commercialized digital tools that enable this practice, the case of the Léo Gravelle website thus entails an examination of a process that calls into question the assumed value of a heritage object and the practices used to ensure that a particular aspect of the past will not be forgotten.

Having completed the time-intensive task of scanning Léo's albums, Denys came up with the idea of constructing a website that could host his digitized clippings and pictures, as well as contain links to Léo's interviews, which are already available online. As he explained:

I've been retired for 5 or 6 years... since December 2006. Firstly, my parents just moved here [in a retirement home] in 2005. And then, we had all the information, and at a certain moment, I said to myself, we are going to do ...I took all the information, the photographs and everything, and I said to myself, we are going to do like that. Perhaps on whim or only to keep... Then Lise, my wife, said "OK, but I 
want to go further with this"... So [ ...] the year after, she digitized everything, everything. I bought her a scanner and then she digitized all the information. (2012, my translation)

9 As this example shows, the increasing accessibility of new technological devices has not only led to a rise in the production of digital artefacts and their storage capacity, but also broadened the range of practices now rendered possible through their digitization. Digital heritagization became one of them, alongside digital scrapbooking and other forms of digital "bricolage". To this extent, the conversion of archival documents into digital format has not only contributed to ensuring their preservation by multiplying supports and venues of conservation, but, as we will see, it gave rise to new forms of family-based heritage now open to (and framed according to) a public gaze. In this case, the aim of archive preservation has thus rapidly been rearticulated by the desire to publicly display personal archives that have been held privately for decades.

The Léo Gravelle website was originally intended to do more than simply display a traditional chronological narrative of hockey memories or serve as a basic repository for personal souvenirs. It moreover constitutes a particular kind of biography displaying the evidence of his different belongings and experiences - some of which having been extraordinary, renowned and as such, mediatized. But as I mentioned above, an important part of the website is dedicated to the display of his family bonds - which are neither especially famous nor related to the hockey milieu. Indeed, the Internet links that refer to family successes (such as the equestrian competitions won by his granddaughter) and the description of the Gravelle family lineage naturally intersect with pictures of Léo's teammates and hockey statistics. In response to my comment that the history of the Gravelle family has become intermingled with descriptions of Léo's hockey career, his son Denys mentioned that for Léo, family "has always come first". Therefore, the Gravelle family story has naturally been integrated into the website, occupying a central place in the narrative and the archival materials conveyed to viewers. The way in which the website has been organized and structured thus emerged from a particular way of life, consequently enabling viewers to access different aspects of Léo's experiences and in unique ways, to gain insight into his private life (in addition to insight into his hockey career). These family archives have thus found a central place in the website and, like the hockey souvenirs, have also become "heritagized".

\section{The rise of unofficial and immaterial heritage}

Over the years, Léo's archives have acquired a particular value, enhanced by the recent heritagization of the Montreal Canadiens team during its centennial anniversary in 2009. Alongside a series of initiatives and products that have been launched and dedicated to glorifying the team's (Valois-Nadeau, 2014), Léo's archives have gained in value. Since they are marked both by a sentimental belonging and a specific cultural context, it seems clear that these archives need to be protected and displayed at the same time, that is to say "heritagized". But as have highlighted Laurajane Smith (2006) and Lucie K. Morisset (2009), heritage is the result of a set of practices which first attest and determine a singular value, rather than revealing an intrinsic quality naturally embedded in one thing or one site. As Laurajane Smith (2006) argues, emerging out of a combination of discourses and social practices that are created and maintained by experts, heritage practices are taking place within specific power relations inscribed in political and 
economic contexts. Flourishing in particular during the 1960's and 70's, at a moment marked by postcolonial claims and the creation of the tourism industry, the discourse of heritage "is reliant on the power/knowledge claims of technical and aesthetic experts, and institutionalized in state cultural agencies and amenity societies" (Smith, 2006:11).

Practiced on a personal scale through the use of digital devices, the heritagization of Léo's archives obviously does not mobilize the same level of expertise, nor the same kind of authority that are usually involved in institutionalized heritage practices. Nevertheless, the question of expertise continues to matter in the digitalization of family-based heritage practices; but in this case, the experts are family members and fans, who, over the years, have developed a keen knowledge of what archival material is most precious. Despite the fact that fans cannot intervene directly on the website, whether it is by adding comments or "liking" posts, the digital platform is nonetheless targeted to a (nostalgic?) audience that loves sport and is also attracted to pictures and stories from previous decades. Considering the increasing public accessibility of digital devices, contemporary heritagization practices do not appear as extensions of a type of heritagization limited to a specific area of expertise or profession. On the contrary, heritagization seems to be practiced by an increasing number of consumers who have a certain level of digital literacy, revealing that the traditional boundaries of heritage preservation are being blurred to an unprecedented degree. Following Harrison (2013), heritage can also be understood as a contemporary practice through which different contextual issues - social, economic and political - are (re)articulated.

Obtaining the status of heritage appears to depend first and foremost on a series of conservation practices that distinguish certain objects from others. Accordingly, this understanding of heritage supports Lowenthal's assertion that "heritage today all but defies definition" (quoted in Harvey, 2001:319) and, by extension, heritage might conceivably occur anywhere and be applied to anything. Applying this principle to an exploration of the variegated forms of conservation and exhibition practices of so-called heritage thus enables an examination of the process, rather than content of heritage, an examination that does not distinguish between the type of expertise involved, be it recognized or not. As Harrison argues, the criteria by which something is given "heritage status" fluctuates:

[W] can see that objects, places and practices may sometimes have both official and unofficial heritage status, and that status has nothing to do with the particular qualities of the "thing" itself, but are defined by values ascribed by those who hold positions of expertise and authority and whose viewpoints are recognised and acted upon by the state (Harrison, 2013:15).

It may seem obvious that the artefacts displayed in the Léo Gravelle website are different from objects that are typically characterized as "heritage": they are taken from personal collections, represent family memories and, unlike conventional heritage objects preserved behind windows or fences, they rarely resonate with collective aspirations. The website's material components, often taken from widely produced media content, do not carry the especially "high public value" that is generally embedded in objects found in official heritage sites such as those protected by UNESCO or other political institutions. In addition to being anchored in family heritage, the digitization of the Gravelle archives becomes an occasion to address the creation of a popular heritage that emerges from consumer and sport cultures, which thereby displaces an understanding of heritage as solely the product of an elitist culture. 

acknowledgement of the different range of values, as well as the intersections of culture and economy, which shape the process and objects involved in heritage preservation. Coupled with the fact that the Montreal Canadien hockey club has established itself as part of Quebec heritage (Annual report of the Montreal Canadien Children Foundation, 2008-2009:15), the materials from Léo's website are part of sport cultures, which have developed their own institutions and practices of heritagization. Always in flux, such heritagization practices are actualized and reactivated in (and by) sport media, auctions, sport museums, biographies of athletes, etc., which all retrace, display, and conserve aspects of sport history that exist outside of legislative and political institutions. Taking form through a range of commodities marked by the team logo kept in private collections, the heritagization has become widespread within a fan culture in which, according to Fiske (1992), the practice of collecting material goods plays an important and well-structured role. Although hockey collectibles might cost considerable amounts of money, as their circulation is regulated by auctions and their value is determined by a wide system of exchange rigorously established by expert collectors, they remain confined to a fan culture, which is usually considered less valuable or legitimate (Storey, 2001). If heritage studies have mainly drawn attention to the supposed national and international heritage of archival material, few researchers in this field have tackled the question of heritage from other milieus and sets of practices, such as those that are at the heart of sport cultures. Such a study could notably bring attention to the economic forces that lie at the heart of this domain, and broaden an analysis that has been typically restricted to the development of tourism or leisure industries and their influence on the selection, disposition or organization of heritage displays.

digital dimension of the Gravelle website also allows for the interrogation of the materiality of the usual understanding of popular heritage. In the past few decades, official institutions such as UNESCO have broadened the definition of heritage, giving more space, visibility and funds to the preservation of what is designated as "immaterial heritage". Usually gathered under the rubric of the "popular," this kind of heritage refers to the traditions that would "naturally" be transmitted across generations and within communities (such as folkloric dances and arts). In addition to giving the impression that a tradition still exists in its genuine and authentic form, this type of heritage simultaneously pushes aside any consideration of the material culture through which the "popular" customs, habits or recipes could be framed, inscribed and transmitted. As demonstrated by Harrison's critique (2013), this understanding of the "popular heritage" directs little attention to the materials that render such practices possible and effective. Harrison argues that popular heritage, whether traditional songs or culinary habits, are cultural practices "embedded in a set of physical relationships with objects, places and other people" (2013:14). Although I address the popularization of heritage practices and even the heritagization of the popular in the case of the Léo Gravelle website, I recognize the material dimension of these archives and their inscription within a cultural formation, even if they are digitized. As Nicholas Chare (2009) argues, even if the archives exist through a digital format, their presence matters and could have an impact and effect that are as significant as those of other types of material. There is a need for a greater recognition of technological materiality and the feeling of authenticity that arise when people engage with these materials, whether through a computer or photo album. Whether digital or traditional, immaterial heritage is inscribed in several practices that 
transform the configuration of places and arouse certain behaviours. Heritage is neither floating nor evanescent. Rather, as the Gravelle website demonstrates, heritage is a practice which affects, and significantly it affects the generations that will follow that which has produced it.

\section{The matter of legacy}

17 If the preservation and exhibition of archives are central to the process of heritagization, their transmission also matters to the realization of this process. Although performed on a micro scale (in effect, among the members of a family), the case of the Léo Gravelle website nonetheless contributes to an understanding of the cultural practice of heritagization and the ways in which digital technologies are reconfiguring this practice. A study of the website thus provides insight into a process that is evolving within a context where the familial bonds are (re-)activated and put forth through many cultural productions. Following Jean Davallon (2006), in this section, I examine how heritagization also constitutes an act of legacy (especially strong within, but not exclusive to, the context of family), where filial bonds are reaffirmed.

Despite the reconfiguration brought by digitization, practices of heritagization have existed at the heart of family structures for centuries. Preserving particular materials and the desire to create a collective identity through legacy are still central to the ways in which heritagization has evolved over time. Although heritagization is situated in particular contexts and subject to legal frameworks, families regulate in their own way the circulation of worthy memory objects and the ascription of meaning and value to these objects. Indeed, some objects are protected and transmitted for generations, while many others are forgotten, broken, or dismissed from a family's future material collection. Inscribed within a particular lineage, objects designated as part of a family heritage embody a particular history, and their transmission over generations inflects the ways that a family's past is narrated. Heritage, whether familial or national, is thus framed and inscribed within internal codes and/or symbolic values shared among groups, regardless of membership or size. The act of transmitting information or objects throughout generations thus matters, whether it is children or citizens who are involved in the transmission. The digital space has become another venue in which this practice occurs.

19 According to Davallon, heritage is marked by an obligation to preserve objects, and it thus differentiates these objects from ordinary commodities, elevating them to the rank of unicity (2006:143). For decades, the eight photo albums dedicated to Léo's hockey past have served as important components of the Gravelle family's objects to remember and commemorate the unique past of their father; they have been separated from the others and protected by plastic covers. Following their digitization, a compilation of Internet links on the Léo Gravelle website complements these photos - an association that otherwise would not be transmitted or kept in the same place.

Whether by conservation, restoration, exhibition or legacy-making, heritagization is shaped and inspired by a specific goal: to ensure that objects of value are not forgotten or damaged in the present, but also to keep them intact and significant for the future. Different time periods thus intermingle through heritagization practices (as for any memory practices). As Edward S. Casey argues about temporalities that overlap in what he called public memory, "this is not to say that the present is of no compelling interest 
in public memory. Often it is: the present is the making, the present that is now, is considered to be of central significance in the future" (2004: 18-19). Indeed, Léo Gravelle's website is a project that matters and resonates in the present, but it also is important and valuable for the future. As a pastime which has slowly transformed in a personal project, the digitization of the Léo's archives and the creation of his website took place in the context where the onset of Denys's retirement and the advancing age of a parent (Léo) had significantly transformed everyday life. These circumstances imbued the future with a particular significance, and provoked a series of actions aimed at promoting posterity. Creating the website at a moment marked by Denys's entrance into a new phase of life has rendered salient that, as Jean Davallon argues, "heritagization acts as a means to manage continuity and moreover, to guarantee permanence" (2006, my translation :133). Heritagization is thus no longer a business merely reliant on the past. As this case shows, and as Casey has pointed out, heritagization is a project oriented and intended for the future and resonates with other practices of memory preservation.

Although the website's digital platform requires continuous human intervention to avoiding its disappearance (even if it is only for the payment of a bill to domain host domain), the construction of the website was planned as an act of preservation and transmission from the beginning. As Denys explained during our interview, the website was imagined as a gift for his children (and Léo's grandchildren). Denys said:

So, how the website has been developed, with the pictures inside, the family... we put a lot of energy [On a mis le paquet], it's not only... You know, our family, Dad when they went on a trip... How could I say that? With the genealogical tree that Lise [Denys's partner] has built, for her own family and mine, [the website] is a complement that we might pass on to our children... A legacy that ... that many people would not be able to.... Because they wouldn't have thought about it. (2012, my translation)

22 As this quote illustrates, the construction of the website intersects with cultural practices (such as genealogy) that involve family. As another place for fixing and performing a family history, this website also demonstrates the popularization of such practices, stimulated and facilitated by the recent digitization of numerous archives. According to van Dijck, (2005), these cultural practices have increased in popularity with the democratization of technological devices, affecting at the same time what is considered a family. Indeed, the digital sources, genealogical databases and devices (such as video cameras and home movies), which capture daily life, have contributed to the constitution and performance of different understandings of family, whether through intergenerational or nuclear models.

According to Will Straw (2007), besides providing a condition for ensuring their perpetuity, the remediation on the Internet of "things" from the past also contributes to their popularity of these items by circulating them to a large audience who can easily access them. By being suddenly integrated in another circuit, digitized "old" materials become revalorized, a process that arouses individuals' sentimental attachments to these materials. Indeed, because the Internet makes it possible to maintain evidence of vanished (and beloved) previous time periods, the preservation of documents and objects thus means more than the perpetuation of the thing in itself; heritagization becomes also a matter of ensuring the continuity of an epoch and fills the gaps between and within different contexts. As Davallon argues:

Designating an object for heritage is a way to go against its disappearance and especially against the disappearance of the world to which it belongs. The 
confirmation of the existence of the world and the attestation that the object is indeed truly from there, therefore poses no problem, inasmuch as the actors who designate the object remain its guarantors since they have its memory and are, as such, the custodians of knowledge about the object and its original world (Davallon, my translation: 134).

Expressing a childhood lived through other codes and values, a sport-spectacle that was less structured and institutionalized than it currently is, and a period when a father was active and autonomous, the Léo Gravelle website is more than just the exhibition of "objects from the past". The website retains the spirit, mood, and way of life of a hockey player in the 1940's and 50's and the rise of his social status, while revealing the specific experiences of a white, working class Francophone man in the province of Québec. Since the website is intended for a wide and unknown public that may include fans of the Montreal Canadiens and certainly the members of the Gravelle family, it became a means to share this knowledge with its "inheritors," who will eventually become its keepers and the guarantors of its perpetuation.

Therefore, as the case of the Léo Gravelle website shows, the process of heritagization is not a disinterested act, nor does it entail a haphazard or "natural" passage of objects from generation to generation. In highlighting the constructed nature and specific contexts in which the practice of heritagization occurs, as well as its "presentification," Davallon explains the inevitable choices and selections made throughout the process. Therefore, in accordance with Annette Kuhn's observations, these choices matter in terms of how we narrate stories about the past: "although we take stories of childhood and family literally, I think our recourse to this past is a way of reaching for myth, for the story that is deep enough to express the profound feelings we have in the present" (2002:1). According to the expression of "inversed filiation" developed by Jean Davallon (2006), those who consider themselves as heritage inheritors thus identify themselves as members of a specific lineage, where "we choose what and how we declare ourselves as 'determined,' we present ourselves as the continuation of what our predecessors have done" (Pouillon, quoted in Davallon, my translation: 97). Given this, practicing heritagization is not only a matter of deciding who is designated as inheritors of a certain heritage to be transmitted, but it is also a matter of who considers themselves affiliated and indebted to it, and who is responsible for maintaining the legacy.

\section{Heritagization and digitization: reconfiguring the possibilities in the present}

The archives previously kept solely in the photo albums represented authentic evidence of Léo's hockey past. Through their digitization and their insertion into the website, they have been (re)organized and (re)placed. Moreover to the addition of explanations describing the archival material and narratives about Léo, these practices have consequently modified the ways in which Léo's hockey past has been presented. Some selected sources are now amalgamated and organized on the website in a way that differs from the photo albums and certain items have been given priority on the website through specific section headings. If the home page serves to relay news about Léo Gravelle (such as the recent admission of some of his personal objects into the collection of the Musée des Sports de Gatineau), others sections of the website are dedicated to presenting information about his family, displaying photographs and a scrapbook that illustrates his membership 
to the Montreal Canadiens Alumni, and providing various links to websites that list Gravelle's statistics as a professional hockey player. The structure of the website thus emphasises the meaningful relationships Léo established during his life. As noted above, other similar archives have been also added to those previously digitized, consequently amplifying the contents of what could be considered to be Leo's heritage. The Internet links referring to Gravelle's television and newspaper interviews thus add to the archive and reinforce its unique value, namely, its ability to distinguish the former hockey player from other men of his generation.

As this article has suggested, heritagization is not only a matter of the preservation of "things". Rather, as this case shows, heritagization is a process that occurs through the organization of heterogeneous material, which usually include a range of highly protected objects, sophisticated systems of conservation, and documentation that explains why these objects are valued so highly (Morisset, 2009). As Harrison suggests (2013), heritage might also be considered as a dispositif that articulates and gives coherence to many elements mobilized during the process. Given this, heritagization is first and foremost a dynamic practice that involves gathering materials as well as persons and places:

Heritage is not a passive process of simply preserving things from the past that remain, but an active process of assembling a series of objects, places and practices that we choose to hold up as a mirror to the present, associated with a particular set of values that we wish to take with us into the future. Thinking of heritage as a creative engagement with the past in the present focuses our attention on our ability to take an active and informed role in the production of our own "tomorrow". (2013:4)

Acting as dispositif, the Léo Gravelle website has thus materialized an active process of assembling materials through the articulation of different narratives, pictures, life stories and belongings from Léo's archives. Although it features almost the same artefacts as those previously collected in photo albums, the website nonetheless entails the rewriting of Léo's story, marked by the feelings and the impetus of the present moment. By being shaped by a set of practices that neither establish nor corroborate their authenticity (Morisset, 2009), the creation of the website has displaced what is usually considered central to the process of heritagization. Indeed, digital heritagization has opened up a space for the emergence of a new creative practice or, to use Harrison's expression, made possible a personal "engagement with the past" through digital media.

This paper highlights the specific ways in which artefacts are deployed, as well as the fact that the technologies used to preserve and perform a past matter in the materialization of this practice. Inspired by a recognition of the influence of technology on representations of the past, as well as its possible effects on the forms that practices of memory take (Frow, 1997; Clermont, 2009), digital heritagization affects the retranslation and reinterpretation of a past and the senses that convey the archives. A preoccupation with the preservation and discovery of an "authentic" past has thus been replaced by concerns about the materiality of the archives and the milieu in which they circulate. These changes related to the practices of heritagization seems thus to underscore the coconstitutive relationship between media and memory (van Dijck, 2005). As van Dijck argues, this mutual relationship influences what is remembered, valorized and preserved:

People's individual cultural memories are structured by the logic of singular media types woven into specific singular practices, such as photography, making home movies or audiotapes. [...]. The cultural forms and practices inherent to these 
singular media technologies unconsciously shape the recording of experiences and thus profoundly affect one's later remembrance of things past (2005: 326).

through his website seem to be assembled to reveal a mode of filiation in which Léo is Léo cultivated and by showing multiple pictures of teammates seen arm in arm, the website produces and (re)activates the belonging of Léo to the prestigious hockey team and, as we have seen above, to his family. The archives' assemblages have written Léo's past as one of fellowship - as a member of the Montreal Canadiens hockey club, its alumni association, his family, his alma maters, and the other hockey teams on which he played. These particular assemblages, used as a way to write Léo's history, produce and reinforce these filiations and shed light on the perpetual actualization of the will to belong (or, in this case, to ensure that a father belongs). Following Elspeth Probyn (1996), belonging is neither an automatic nor an immanent state; belonging (including that of a father) is rather a matter of desire that is materialized, in this case, by practices of heritagization.

This particular way of presenting Léo's affiliation echoes conventional historical narratives about professional athletes. Biographies and media interviews with sports stars frequently reiterate their exploits, statistics, and records, but also promote nostalgia through their descriptions of the experiences athletes shared with their teammates that hail from another time. As the ethnographic work of Michael Robidoux has shown, the intensity of the sport, as well as the long hours spent together on the road contributes to the intimacy that develops among players, making them, "like a big family", "knit or 'gelled' into one" (2001:127). Additionally, the reminder of times past and the closeness that existed between teammates takes on a unique significance within the contemporary context in which elders are frequently marginalized and excluded from public spaces. In explicitly re-inscribing Léo in a particular history and community, enlivening his lineage and presenting it online, playing with the archives of an elder intersects with a discourse on the social inclusion of elders and a better recognition of their place in society. 


\section{Conclusion: The contribution of the analysis of digital heritagization}

This analysis of Denys Gavelle's personal project sheds light on new forms of digital heritagization which (re)articulate in a unique way conventional conceptions of heritage and its practice. This case, made possible through the arrangement of archival materials and distinguished by an individual's appropriation of these materials, demonstrates that digital heritage is first and foremost a cultural practice evolving among (and certainly inspired by) others cultural practices. Co-existing with other forms of institutionalized heritage, this case highlights that new digital media practices do not completely transform heritagization nor do they introduce heritage into completely unfamiliar venues. On the contrary, the Léo Gravelle website recreates the major patterns at the heart of the process of heritagization, such as the desire to preserve archives, the exhibition of a past that is framed in a particular way, and the transmission of knowledge. It is also important to mention that Léo's heritage still exists outside the digitization of his archive; the photo albums (for example) are still very well preserved. Inspired by a son's desire to acknowledge Léo's past, the creation of the website coexists with other projects that continue to recognize and to maintain Léo's past, such as a petition that the Gravelle family initiated (linked to from the website) to re-name Léo's hometown arena after him. To that extent, the passage of Léo Gravelle's particular story into a digital space has rather increased the visibility of such practices.

The exploration the Léo Gravelle website also reveals that digital heritagization also shares the effects of "regular" and official forms of heritage. As Harrison states (2013), the designation of objects, places or cultural traditions as heritage contributes to the valorization and the normalization of certain behaviours and habits. According to this perspective, this website contributes to the normalisation of specific values and traditional institutions, such as the nuclear family. The value of family was expressed several times during the interview conducted with the Gravelles and family occupies an important place in the ways that the archives are displayed and organized on the website. Thus, despite being conducted through a new format, the value of family remains at the heart of heritagization processes. The website, as a project initiated by a son about his father in order to create a legacy for grandchildren (additionally as a family tree and a means to remember Denys's childhood), has multiplied the possible forms of familial relations that emerge through heritage processes.

In light of this exploration, the major changes brought about by the digitization of heritage seem related to the declining importance of authenticity and the rise of other regimes of value (Frow, 1995; Morisset, 2009) usually not associated with heritage. By virtue of its accessibility, which extends expertise to a wide range of individuals, digital heritagization similarly inflects the nature of the material that becomes designated as heritage. In this context, an exploration of the process of heritage appears to be more relevant than an inquiry into the authenticity of digital archives. Digital heritage might make the cultural and contextual processes by which heritagization occurs more obvious and the co-constitutive relationship between media and memory might become more easily recognized through a study of the digital mediation of archives.

The creation of the Léo Gravelle website has thus provided an opportunity to interrogate the implications of the online heritagization of a father's filiation through a wide range of 
materials. Although this form of heritagization is made possible through a computer and operates in a virtual space, it is just as effective as heritage practices produced through other forms of materiality. As Nicholas Chare (2009) states, playing with archives allows one to be in touch with a past, even if one has not personally experienced this past. By adding another venue for the deployment of archives and continuing to make the organization of archival material possible, the digitization of archives has thus increased the ways individuals can engage with archives, regardless of their format. According to van Dijck (2005), despite the digital erasure of material inscriptions and the potential for individuals to alter or modify content, the fact remains that

Digital technologies seem to promote a different materiality that both complements and partially replaces analogue objects embodying memory; most importantly, they shape the very nature of remembering as they become (literally) incorporated in our daily routines of self-formation (2005: 329).

Finally, this exploration has contributed to an abandonment of the myth of permanence through digital inscription, highlighting the following paradox: digital heritagization is a practice that aims to secure the ephemeral by maintaining in the present objects intended for the future. As Wendy Kyong Hui Chun suggests, the specificity of the current digital culture of memory (within which digital heritagization could be inscribed) "is its conflation with storage, which produces the odd, almost paradoxical idea of enduring ephemerality, of the intimate coupling of degeneration and regeneration that is at the core of how memory functions technically as well as culturally" (quoted by Parikka in Ernst, 2013:16). In offering an alternate means and venue to stabilize the ephemeral, to fix a story (despite being, as a website, inclined to change), the website nevertheless contributes to increase the public presence of Léo Gravelle despite the fact that he is deceased. Although the former Montreal Canadien's physical presence no longer exists, he continues, at least, to be present online through the archives preserved on the website.

\section{BIBLIOGRAPHY}

CASEY Edward S. (2004). "Public Memory in Place and Time", in Kendall R. Philips (ed.) Public Memory, Tuscaloosa, University of Alabama Press, pp. 17-44.

CHARE Nicholas (2009). "Warring Pixels. Cultural Memory, Digital Testimony, and the Conflict in Iraq", Convergence: The International Journal of Research into New Media Technologies, 3 (15), pp. 333-345.

CLERMONT Patricia (2009). De la mémoire au mémoriel. Analyse de la constitution et de l'effectivité de deux personnalités publiques au Québec. Éléments d'une problématique du mémoriel. (Thèse de doctorat inédite), Université de Montréal.

DAVALLON Jean (2006). Le don du patrimoine : une approche communicationnelle de la patrmonialisation, Paris, Hermès science.

HARRISON Rodney (2013). Heritage. Critical Approaches, London \& New York, Routledge. 
FISKE John (1992). "The Cultural Economy of Fandom”, in LEWIS Lisa. A. (ed.) The Adoring Audience. Fan Culture and Popular Media, London, Routledge, pp. 30-49.

FouCAult Michel (1994). «Sur l'archéologie des sciences. Réponse au Cercle d'épistémologie » in Defert Daniel \& Ewald François (ed.) Dits et écrits Tome 1, Paris, Gallimard, pp. 696-731.

FROW, John (1995). Cultural Studies \& Cultural Value, Oxford, Clarendon Press.

FROW John (1997). Time and Commodity Culture : Essays in Cultural Theory and Postmodernity, Oxford, Oxford University Press.

GRENIER Line (2001). "In Search of an Archive: Methodological Issues in the Genealogical Analysis of the Popular Music Industry in Quebec", Canadian Journal of Communication, 2 (26), pp. 277-283.

HARVEY David C. (2001). "Heritage Pasts and Heritage Presents: temporality, meaning and the scope of heritage studies", International Journal of Heritage Studies, 4 (7), pp. 319-338.

KUHN Annette (2002). Family secrets. Acts of memory and imagination, London \& New York, Verso [1995].

MORISSET Lucie. K. (2009). Des régimes d'authenticité. Essai sur la mémoire patrimoniale, Rennes \& Québec, Presse universitaires de Rennes \& Presses de l'Université du Québec.

PARIKKA, Jussi (2013). “Archival Media Theory: An Introduction to Wolfgang Ernst's Media Archeology", in Ernst Wolfgang, Digital Memory and the Archive, Minneapolis, University of Minnesota Press, pp.1-22.

PROBYN Elspeth (1996). Outside Belongings, New York \& London, Routledge.

ROBERTS Les \& COHEN Sarah (2013). “Unauthorising popular music heritage: outline of a critical framework", International Journal of Heritage Studies, 3 (20), pp. 241-261.

ROBIDOUX Michael (2001). Men at play. A working understanding of professional hockey, Montreal \& Kingston, McGill-Queen's University Press.

SMITH Laurajane (2006). Uses of heritage, London \& New York, Routledge.

STOREY John (2001). Cultural Theory and Popular Culture, London, Pearson Educational Limited.

STRAW Will (2007). "Embedded Memories", in Acland Charles (ed.) Residual Media, Minneapolis, University of Minnesota Press, pp. 3-15.

VALOIS-NADEAU Fannie (2014). Un centenaire, des faire mémoire. Analyse des pratiques de mémoire autour du Canadien de Montréal, (Thèse de doctorat inédite), Université de Montréal. VAN DIJCK José (2005). "From Shoebox to Performative Agent: The Computer as Personal Memory Machine”, New Media \& Society, 3 (7), pp. 311-332.

VAN DIJCK José (2007). Mediated Memories in the Digital Age, Redwood City, Stanford University Press.

\section{NOTES}

1. Comptois Martin (2013, 31 octobre). «La Gazelle n'est plus », Le Droit. Retrieved from http://www.lapresse.ca/ledroit/ sports/canadien/201310/30/01-4705557-leo-gravelledit-la-gazelle-nest-plus.php

2. The interview and the website analysis have been realized in 2012 in the midst of my doctoral dissertation on the centennial anniversary of the Montreal Canadien hockey team. The website 
and the interview have been processed as materials collected in an archive that I especially created for my research (Grenier, 2001; Foucault 1994). Constituting an archive, rather than using other qualitative methods such as content analysis, enables me to retrace the diversity of practices of memory and the heterogeneity of the visual and discursive materials through which they are performed. To that extent, the interview has served as to complement the information so to provide more details on the ways, the how and the why, heritagization has been realized by the members of the family. The purpose of this was to enable me to follow the dynamism and the transformation of these cultural practices.

3. If the homepage is dedicated to the public acknowledgement of Leo's career (which goes from the petition for having an arena named after him to the videos of his recent interviews), an important part of the website is intended for the exposure of his scrapbook, his family and his photographs. All these tags are the headings of different sections of the site, through which the artefacts are saved.

4. Unfortunately, the counter was not working at the time when this article was written, and an error message appeared in its place.

\section{ABSTRACTS}

This article interrogates the process of heritagization that occurs through the creation of the website dedicated to Léo Gravelle, a former Montreal Canadiens hockey player. This website, created by Léo Gravelle's son, became an alternate venue to circulate and render accessible his professional hockey career by featuring private photographs alongside newspaper clippings, memorabilia and other personal archives. As a way to provide a wide exposure of Léo's hockey past, facilitate public access to his personal archives that had been accumulated over many years, and ensure their preservation in the future, the creation of this website sheds light on heritage practices realized on a small and familial scale, at the intersection of unofficial heritage, digital heritage and familial heritage. Drawing on an analysis of the website and an interview conducted with the Gravelles, the article explores how this process of heritagization is framed - and transformed - by the possibilities provided by digital technologies, as well as by the cultural practices and familial ties that lie at the heart of the project The analysis of the digital heritagization practices initiated by family members occurring within the context of consumer culture and sport-spectacle opens up and challenges the way heritage is generally understood and established.

Cet article interroge le processus de patrimonialisation qui advient à travers la création du site Internet consacré à Léo Gravelle, ancien joueur de l'équipe de hockey professionnel Canadien de Montréal. Ce site Internet, créé par un des fils de Léo Gravelle, est devenu un lieu alternatif pour faire circuler et rendre accessible le récit de sa carrière de hockeyeur professionnel, et ce par la diffusion de ses photos personnelles, de coupures de journaux et autres souvenirs personnels. En accordant une grande visibilité au passé de Léo, en facilitant un accès public à ses archives personnelles et en assurant leur préservation future, la création de ce site Internet met en lumière des pratiques de patrimonialisation réalisées à petite échelle, au croisement de pratiques issues du patrimoine non-officiel, numérique et familial. Tiré d'une analyse du site Internet et d'une entrevue réalisée avec les Gravelle, cet article explore comment le processus de patrimonialisation s'est constitué - et transformé - par les possibilités fournies par les 
technologies numériques, de même que par les liens familiaux qui sont au cœur du projet. L'analyse des pratiques de patrimonialisation numérique initiées par les membres d'une même famille et survenant au sein du milieu du sport-spectacle et dans une culture de consommation, permet alors d'ouvrir et de défier les façons dont le patrimoine est compris et établi.

INDEX

Mots-clés: Patrimonialisation, archives familiales, préservation, hockey sur glace, Canadien de Montréal, analyse médiatique

Keywords: heritagization, familial archives, preservation, ice hockey, Montreal Canadians, media analysis

\section{AUTHOR}

\section{FANNIE VALOIS-NADEAU}

Department of Communication Studies, Concordia University \& School of Kinesiology and Health Studies, Queen's University 